\title{
Managing the process of machining on machines on the basis of dynamic modelling for a technological system
}

VIACHESLAV MAKSAROV - Department of Mechanical Engineering,

Saint-Petersburg Mining University • maks78.54@mail.ru

ALEKSEY KHALIMONENKO - Department of Mechanical Engineering, Saint-Petersburg Mining University • khalim76@spmi.ru

JüRI OLT - Department of Production Engineering, Institute of Technology, Estonian University of Life Sciences • jyri.olt@emu.ee

Érkezett: 2017. 04. 22. - Received: 22. 04. 2017. " https://doi.org/10.14382/epitoanyag-jsbcm.2017.12

\section{Abstract}

The article considers the issues related to improving the efficiency of multipoint machining by the use of rotary cutters which are equipped with replaceable ceramic inserts on CNC machines by developing a method of multipoint machining process control. A dynamic model is proposed for the multipoint cutting process on the basis of continuum theory, and a mathematical model which is cognisant of the specific nature of the multipoint metal cutting problem, and ensuring efficiency in the description of various chip-making process modes.

Keywords: multipoint machining, dynamic model, cutting process, generic mathematical model, milling.

\section{Introduction}

At present, process control in mechanical engineering is one of the most promising directions of development in this field. Improving the efficiency of multipoint cutting by means of rotary tools which are equipped with replaceable ceramic bits determines the need for the widespread use of highperformance equipment which permit automated machining processes. The control of machining processes in automated production is only possible on the basis of new approaches to the study of the phenomena which accompanies the metal cutting process.

The loss of stability in the multipoint cutting process results in self-oscillation, increasing the intensity of cutting tool wear and reducing the service of machine operating mechanisms; it also leads to deterioration of machining quality and accuracy $[1,2]$. Therefore, reducing the intensity of any oscillation in industrial process systems which are operated on an automatic cycle mode is at present a pressing issue $[3,5,7]$.

Creating preliminary local physical impact (LPI) on the external surface of the layer which is being sheared off is, according to certain laws, one of the most efficient methods of allowing metal deformation conditions to be changed during cutting [8]. Periodical changes of cutting conditions as compared to the basic material are a peculiarity of the process of machining the work pieces subjected to such action. Such a method allows to carry out control of the multipoint cutting process, in its turn affording the opportunity to improve the multipoint machining technology in a wide range of materials and cutting conditions $[4,8]$.

The following problems should be solved successively in order to implement the proposed method:

- isolating the causes of emergence of plastic deformation instability and the conditions of transition to an unstable state in the process of multipoint cutting leading to self-oscillations excitation in the closed process scheme of machining by cutting $[2,10]$;

- choosing and substantiating the rheological model of multipoint cutting process allowing to carry out dynamic modelling of machining process system [8, 13];

- developing a dynamic model of industrial process system with regard for rheological peculiarities of multipoint cutting process and oscillations in the closed system loops on the basis of dynamic models proposed earlier $[6,9,12]$;

- developing a theoretical basis for efficient control of multipoint machining industrial process systems deformation process and vibration immunity $[3,10]$;

- carrying out a set of experimental studies with the purpose of confirming the validity of the theoretical ideas obtained in the process of previous work [7];

- developing guidelines for improvement of the efficiency of multipoint cutting industrial process on the basis of chip formation process control [11].

\section{Materials and methods}

Before the experimental studies, available research papers have been analysed. The analysis allowed to select hypotheses about the sources of self-oscillations onset in the machining industrial process system. The principal hypotheses are as follows:

- the existence of a coordinate connection in an elastic system in the presence of nonconservative cutting force;

- closeness of the machine dynamic system in the presence of cutting dynamic response; 
- delay of cutting forces as compared to the respective disturbances arising upon local deformation of metals in the process of cutting.

The hypothesis of cutting forces delay connected to plastic deformation delay is used most frequently in dynamical analysis. It is adopted that the delay of both kinds of forces as compared to the respective disturbances inevitable upon breaking strain of viscoelastic metals is the phenomenological factor making system instability possible.

A study was undertaken in order to find out whether it is possible to suppress the self-oscillations arising in the process of cutting by local physical impact (LPI). The study allowed to extract formulas to assess the degree of local physical impact influence on the dominant system beyond the stability area boundary as the LPI is created and applied to the surface being machined by various methods.

The proposed study flow chart allowed to assess the influence of local physical impact on the cutting kinematics. It is possible to find out the regularities with whose help it is possible to assess possible LPI depth, allowing to suppress the self-oscillations arising in the system by implementing the proposed scheme of mutual arrangement of the local physical impact area and the area of transversally sheared-off layer of chips during multipoint machining (Fig. 1).

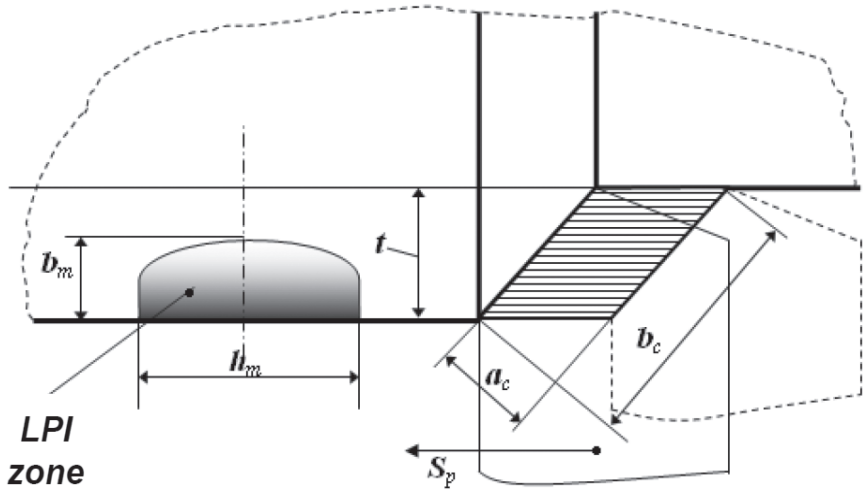

Fig. 1. Diagram of mutual arrangement of the local physical impact area and the transversally sheared layer of chips: $S_{p}-$ feed direction, $a_{c}$ and $b_{c}-$ width and thickness of the layer being sheared off, $t$-cutting depth, $b_{m}$ and $h_{m}-L P I$ depth and width.

1. ábra A lokális megmunkálási terület és a keresztirányban leválasztott forgács kölcsönös viszonya: $S_{p}$ - előtolás iránya, $a_{c}$ és $b_{c}$ - a leválasztott réteg szélessége és vastagsága, $t$-fogásmélység, $b_{m}$ és $h_{m}$ - LPI mélysége és szélessége.

Analysis of the research papers study result allowed to present the process of plastic metals cutting by the following diagrams (Fig. 2).

The obtained data allowed to carry out mathematical modelling of chip formation in the process of cutting [12]. Physical properties of the metal being deformed can be visualized as a mechanical analogy (a discrete rheological model) presented as a certain totality of mechanical elements: elasticity, viscosity and plasticity, allowing to come over to the implementation of a generalized rheological model in the form of a series combination of the elastoviscoplastic relaxing Ishlinsky medium and the Voigt medium with deformation delay (Fig. 3).
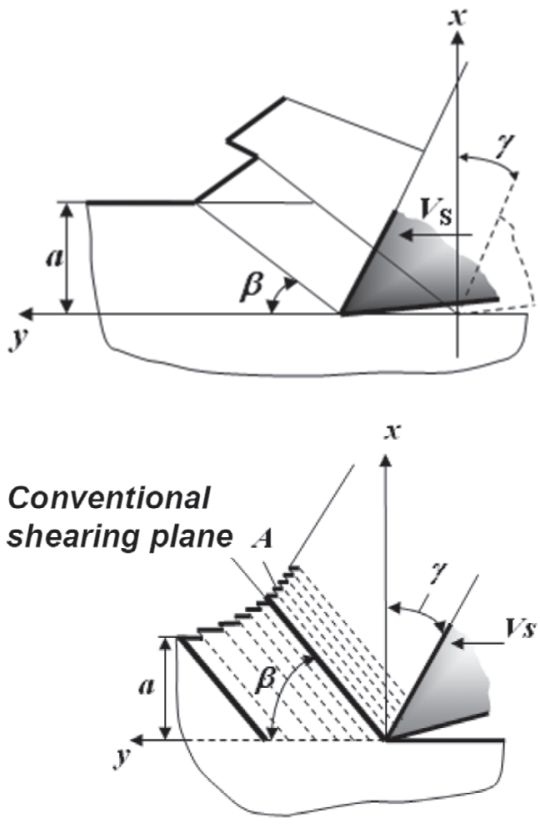

Fig. 2. Conventional model of chip making process: a) - formation of saw-shaped chip elements; $b$ ) - formation of laminose fine texture where $S$ is feed direction, $\beta$ is shear angle, $\gamma$ is face angle, $a$ is thickness of the layer being sheared off.

2. ábra Forgácsképződés hagyományos modellje: a) - forgácselem leválasztása; $b$ ) - finom textúra kialakulása, ahol $S_{p}$ az elötolás iránya, $\beta$ anyírási szög, $\gamma$ a felületi szög, a a leválasztott réteg vastagsága.

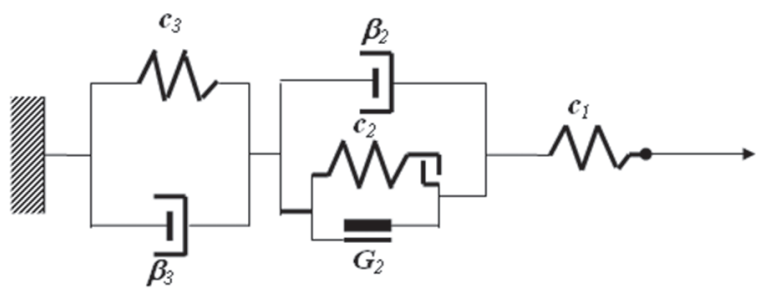

Fig. 3. Rheological model of chip formation in the process of cutting: $G_{2}, c_{1}$ are quasielastic and dissipative coefficients.

3. ábra Forgácsképződés reológiai modellje forgácsolás során: $G_{2}, c_{1}$ a kvázi-rugalmas és disszipatív együtthatók.

Such a combination of elements reflects dynamic interaction between the process of metal plastification in the layer being sheared off (Ishlinsky medium) and the process of removed chips deformation and friction (Voigt medium), and therefore, describes the cutting process in sufficient detail $[8,11]$.

Having presented the rheological model of chip formation in the operator form and having carried out the appropriate transformation, we obtain formulas $(1,2)$ characterizing the process of a body reversion to its undeformed state expressed through the principal characteristics of relaxation.

$$
\begin{aligned}
& \tau_{r e l}^{(1)}=\frac{1}{\gamma_{3}+\omega}=\frac{c_{3}}{2 \cdot \beta_{3}}+\frac{c_{2}}{2 \cdot \beta_{2}}+\left|\frac{c_{3}}{2 \cdot \beta_{3}}-\frac{c_{2}}{2 \cdot \beta_{2}}\right| \\
& \tau_{r e l}^{(2)}=\frac{1}{\gamma_{3}-\omega}=\frac{c_{3}}{2 \cdot \beta_{3}}+\frac{c_{2}}{2 \cdot \beta_{2}}-\left|\frac{c_{3}}{2 \cdot \beta_{3}}-\frac{c_{2}}{2 \cdot \beta_{2}}\right|
\end{aligned}
$$

where $\gamma_{3}$ and $\omega$ are, respectively, damping factor and frequency, $c_{2}, c_{3}$ are quasi-elastic and $\beta_{2}, \beta_{3}$, are dissipative coefficients.

The dependencies determined above allowed us to come over to dynamic modelling of the machining industrial process system during multipoint cutting by rotary cutters equipped 
with ceramic bits. A simplified dynamic model was developed for that purpose. That model was based on the industrial process system element parameters measured on the milling machine used for the experiments: reduced mass $m$, resistance force to speed proportionality coefficient $b$ and stiffness coefficient $c$.

For a torsional system, respectively: reduced inertia moment $J$, proportionality coefficient $b_{\phi}$ and torsional stiffness coefficient $c_{\phi}$.

Natural loop oscillations and logarithmic decrement frequencies were determined in the same way. The apparatus used for that purpose included an inertia oscillation sensor with an intermediate amplifier, a NI SC-2043-SG analogdigital converter board and a computer on which a LabVIEW 13.0 data processing system was installed. A virtual instrument for receiving and post processing of damped oscillation was created in it. Load to displacement dependency diagrams were plotted on the basis of the measurements. Those diagrams were used to determine system element stiffness coefficient.

As a result, the simulation model boiled down to a simplified system of a quadruple dynamic module of the small-size machining industrial process system (Fig. 4) with dissipative characteristics taking into account the structural damping and rheological processes of the global model under consideration to which two subsystems with four generalized coordinates correspond:

a) is the work piece subsystem $B$ with coordinates $u, w$;

b) is the tool subsystem $T$ with coordinates $x, y$;

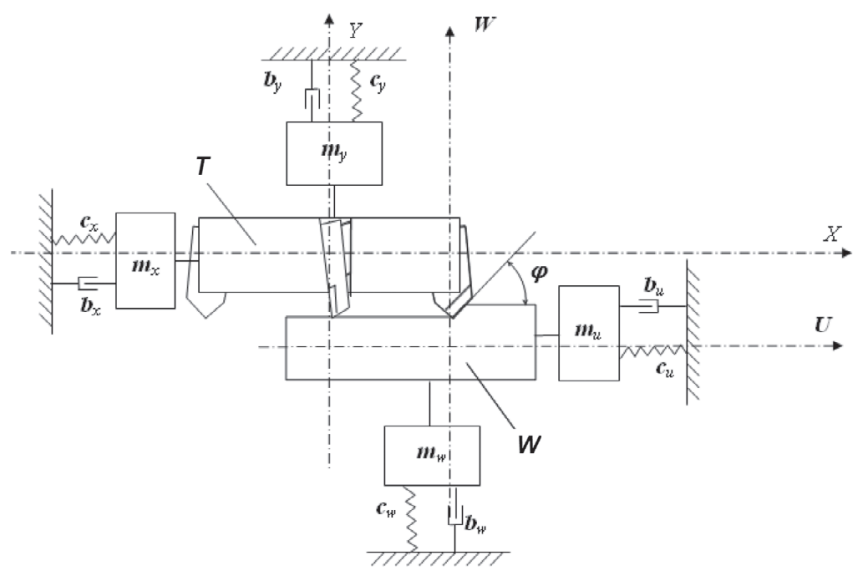

Fig. 4. Dynamic model of a quadruple industrial process system: $W$ - work piece; $T$ - Tool; $X, Y$ - tool axes; $U, W$ - work piece axes; $m, m, m_{v}, m_{w}$ - reduced inertia parameters; $b_{x}, b_{y}, b_{u^{\prime}}, b_{w k}$ - energy dissipation coefficients; $c_{x^{\prime}} c_{y}, c_{u^{\prime}} c_{w}-$ stiffness coefficients.

4. ábra Négy szabadságfokú megmunkálási rendszer dinamikus modellje: $W$ munkadarab; T-szerszám; $X, Y$ - szerszámtengelyek; $U, W$ - munkadarab tengelyei; $m_{x^{\prime}} m_{v}, m_{u^{\prime}} m_{w}-$ redukált inercia paraméterek; $b, b, b_{u^{\prime}} b_{w k}-$ energia disszipációs együtthatók; $c_{x}, c_{y}, c_{u^{\prime}} c_{w}$ - merevségi együtthatók.

The subsystems communicate through the chip making process presented by a rheological model in the normal $n$ and tangent $\tau$ directions (Fig. 5). The chip making process can be conventionally divided into two stages: deformation before the shearing plane $\left(\sigma<\sigma_{p l}\right)$ and shearing of an element of small thickness along the shearing plane $\left(\sigma \geq \sigma_{p l}\right)$. In the process of building differential equation systems of the quadruple model of machining industrial process system, the transition condition can be presented as an inequality system: with $\sigma<\sigma_{p l}, c_{1 \tau} \cdot(x-u)^{2}+c_{1 n} \cdot(y-w)^{2} \geq \sigma_{p l} \cdot S_{s h}(3)$ with $\sigma \geq \sigma_{p l}, c_{1 \tau} \cdot(x-u)^{2}+c_{1 n} \cdot(y-w)^{2}<\sigma_{p l} \cdot S_{s h}(4)$ where $x, y, u, w$ are the mechanical system coordinates; $c_{1 \tau}, c_{1 n}$ are stiffness coefficients characterizing the elastic behavior of chip formation rheological model in the lines $\tau$ and $n, \mathrm{~N} / \mathrm{m} ; \sigma_{p l}$ is the yield (plasticity) limit, $\mathrm{N} / \mathrm{m}^{2} ; S_{s h}$ is the area of the layer being sheared off $(a \times b)$ in $\mathrm{mm}^{2} ; \beta$ is the shearing angle.

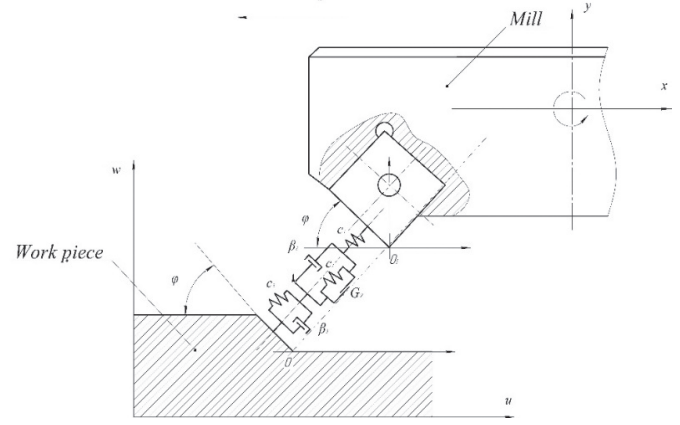

Fig. 5. Rheological model of chip formation in the process of cutting: where: $c, G$ $\beta$ - quasi-elastic and dissipative coefficients ( $n$ - normal, $\tau$ - tangent), $\varphi$ entering angle.

5. ábra Forgácsleválasztás reológiai modellje: ahol c, G, $\beta$ - kvázi-rugalmas és disszipatív együtthatók ( $n$ - normál, $\tau$ - érintö), $\varphi$ - homlokszög.

In a number of cases, chips friction against the front tool surface caused by eternal friction and secondary plastic deformation of the chips layer is accompanied by adhesion phenomena on the micro areas of the chips to tool elastic contact. That being the cased, it was established that this physical phenomenon between the tool and the chip can be presented as two phase transitions: sliding and seizure $[6,11]$.

Transition from one phase to the other is shaped sequentially by the system itself. The conditions for phase transitions implementation are determined by kinematic and force characteristics of subsystems interactions and expressed as a switchover function $\operatorname{Sg}(w)$ :

$\operatorname{Sg}(w)=\left\{\begin{array}{l}w>[V] \\ w \leq[V]\end{array}\right.$

where $\boldsymbol{w}=\boldsymbol{V}_{S}+\dot{\boldsymbol{x}}-\dot{\boldsymbol{u}} ; V_{s}$ is cutting speed, $\dot{\boldsymbol{x}}$ and $\dot{\boldsymbol{u}}$ are the work piece and the tool subsystem speeds.

That being said, the behavior of the selected dynamical quadruple model of machining industrial process system in accordance with the adopted rheological model of chip forming is presented in general terms as a system of differential equations:

$T_{x 2}^{2} \ddot{x}+\left(T_{x 1}+T_{x 3}\right) \dot{x}-T_{x 3} \dot{u}+2 x-u=Q ;$

$T_{y 2}^{2} \ddot{y}+\left(T_{y 1}+T_{y 3}\right) \dot{y}-T_{y 3} \dot{w}+2 y-w=P$;

$T_{u 2}^{2} \ddot{u}+\left(T_{u 1}+T_{u 3}\right) \dot{u}-T_{u 3} \dot{x}+2 u-x=-Q$;

$T_{w 2}^{2} \ddot{w}+\left(T_{w 1}+T_{w 3}\right) \dot{w}-T_{w 3} \dot{y}+2 w-y=-P$;

$\left(T_{P}+T_{P 1}\right) \dot{P}+P=-\left(k_{x}-k_{P X}\right)(x-u)-$

$-\left[T_{k y 1}-k_{P Y}\left(T_{P}+T_{P 2}\right)\right](\dot{y}-\dot{w})+$

$+k_{P Y}(y-w)-\left[k_{x} T_{P 1}-k_{P X}\left(T_{P}+T_{P 2}\right)\right](\dot{x}-\dot{u})$

$T_{Q} \dot{Q}+Q=P-T_{k x}(\dot{x}-\dot{u})-T_{k y 2}(\dot{y}-\dot{w})$ 
where $T_{x 2}, T_{y 2}, T_{u 2}, T_{w 2}$ are loop time constants $x, y, u, w ; T_{x 1}, T_{y 1}, T_{u 1}, T_{w 1}, T_{x 3}, T_{y 3}, T_{u 3}, T_{w 3} \quad$ are loop damping time constants $x, y, u, w ; k_{x}$ is system loop $x$ transmission coefficient; $T_{P}, T_{Q}$ are time constants; $k_{P x}, k_{P y}, T_{P 1}, T_{P 2}$ are coefficients and time constants in view of rheological peculiarities of the chip making process. The system of differential equation (6) was solved by the piecewise approximation method. For that purpose, this system was presented in the vector-matrix form:

$T \cdot \dot{q}+N(q) \cdot q=0$

where $q-(n \times 1)$ is the vector-function of generalized system coordinates; $T$ is lumped size matrix $(n \times n) ; N(q)$ is size matrix $(n \times n)$. In the model under consideration $n=10$; whereupon the number of loops $n$ corresponds to the model size.

\section{Results and discussion}

On the ground of the rheological models developed above, the problem of controlling the process of multipoint cutting with ceramic bit rotary cutters by the face milling method. The relationship between the volume of the local impact zone with altered structure and properties $\mathrm{W}_{\text {LPI }}^{\prime}$ and the total volume $\mathrm{W}_{\mathrm{ch}}^{\text {, }}$ of the metal layer sheared by one bit in the LPI area:

$\frac{W_{L P I}^{\prime}}{W_{c h}^{\prime}}=\frac{b_{m} h_{m}}{2 \pi t\left[D\left(\cos \psi_{H}-\cos \psi_{K}\right)+S_{Z}\left(\frac{\psi_{H}-\psi_{K}}{2}+\frac{\sin \psi_{K}-\sin 2 \psi_{H}}{4}\right)\right]}$

where $\psi_{H}$ is the LPI zone bit entry angle, $\psi_{K}$ is the LPI zone bit exit angle, $D$ is the rotary cuter diameter, $S_{Z}$ is the bit feed, $h_{m}$ is the local impact zone width, $b_{m}$ is the LPI zone depth, $t$ is milling depth determining the reliability and efficiency of periodically changing stress-strain state conditions in the cutting zone needed for controlling the multipoint cutting process.

Fig. 6 presents the general appearance of a cylinder block face that must be machined in compliance with the technical requirements for mating face accuracy $(0.03 \mathrm{~mm}$ for $100 \mathrm{x} 100$ $\mathrm{mm}$ size) and surface roughness $R_{a}=1.6 \mu \mathrm{m}$ (Fig. 7).

The implemented set of comparative calculation and experimental studies of work pieces milling with a wide variation of machining parameters allowed us to propose a scheme of local physical impact application to the work piece surface being machined modelling the cylinder block face (Fig. 8).

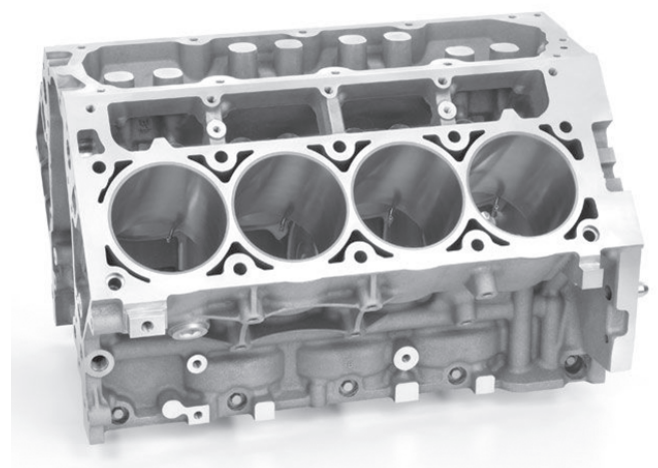

Fig. 6. General appearance of the cylinder block face.

6. ábra A hengerblokk felület általános képe.

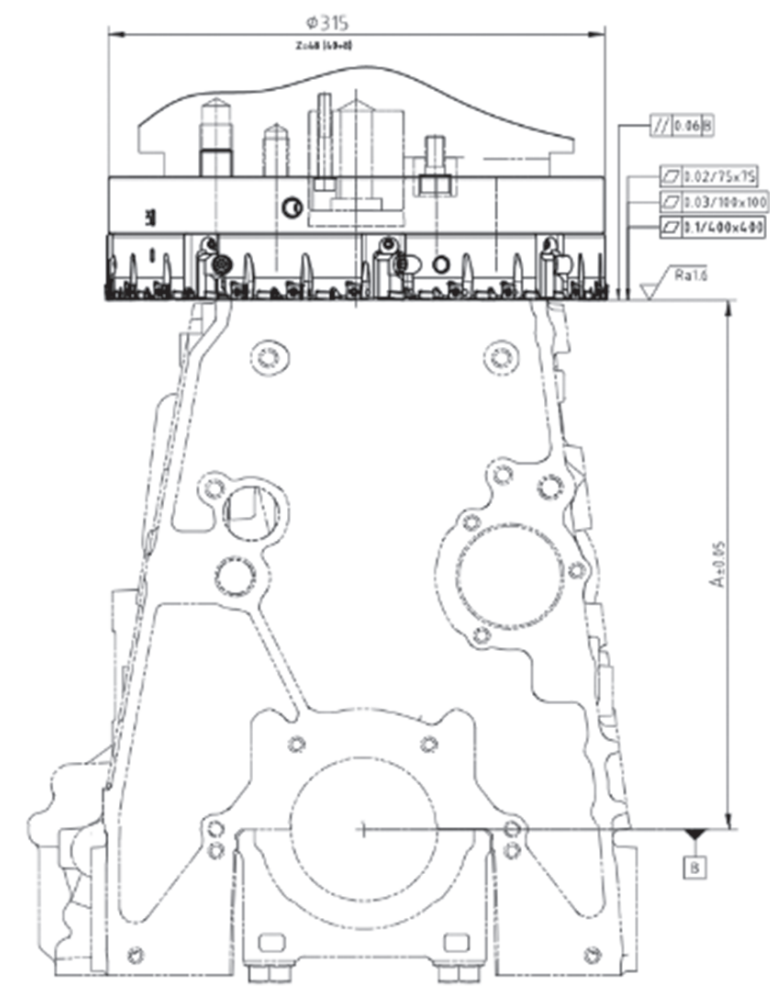

Fig. 7. Technical requirements for the cylinder block face.

7. ábra Technikai követelmények a hengerblokkra vonatkozóan.

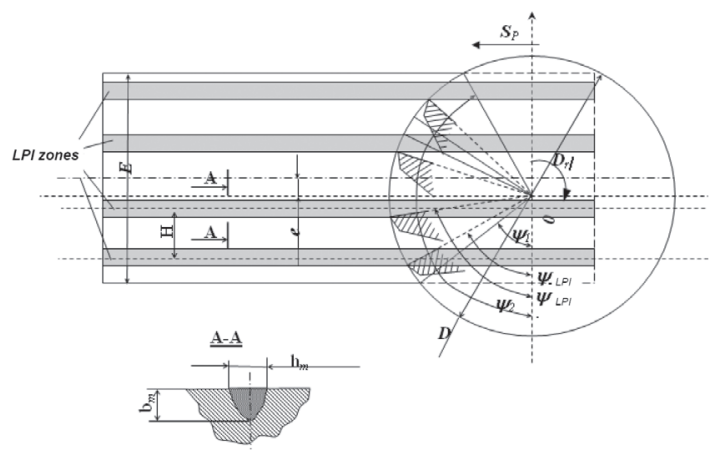

Fig. 8. LPI zones layout diagram during face milling: $E$ - work piece width; $e-$ rotary cutter axis to work piece axis offset; $S_{p}$ - feed direction; $D$ - rotary cutter diameter; $D_{r}$ - rotary cutter rotation direction; $\psi_{1}, \psi_{2}-$ bit work piece entry and exit angles; $\psi_{L P P}, \psi_{L P I 2}-$ LPI bit entry and exit angles; $H$-distance between LPI zones; $h_{m}$ and $b_{m}$ - LPI zone width and depth.

8. ábra LPI zónák elhelyezkedése fúrás során: $E$ - munkadarab szélessége; $e$ fúrótengely eltolása a munkadarab tengelyhez képest; $S_{p}$ - elötolás iránya; $D$ - fúró átmérő; $D_{r}$ - fúró forgásiránya; $\psi_{1}, \psi_{2}$ - fúrószerszám belépési és kilépési szöge; $\Psi_{L P P} \Psi_{L P I 2}$ - LPI belépési és kilépési szög; $H$ - távolság az LPI zónák között; $h_{m}$ és $b_{m}$ - LPIzóna szélessége és mélysége.

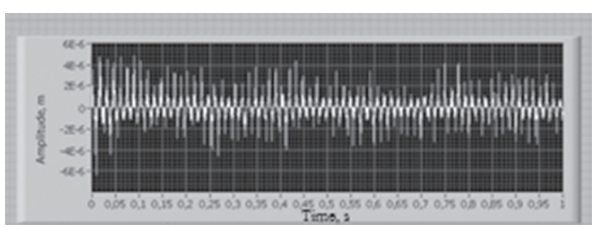

Fig. 9. Calculated (a) and experimental (b) vibration displacement during face milling of Gh190B grade cast iron.

9. ábra Számított (a) és kísérleti (b) rezgéskép Gh190B minőségü öntöttvas felületi fúrása során.

A comparison of calculation (Fig. 9.a) and experimental (Fig. 9.b) data has shown that the difference between theoretical and practical results does not exceed $15 \%$, which is evidence of 
qualitative concordance of the nature of oscillations and affords grounds for claiming that the rheological models developed by us are operable.

Experimental studies of face milling of the mating face of a Gh190B grade cast iron cylinder block over a discontinuous surface using local metastability allows to obtain maximum deviation within $0.015 \mathrm{~mm}$ in rapid machining modes (Fig. 10).

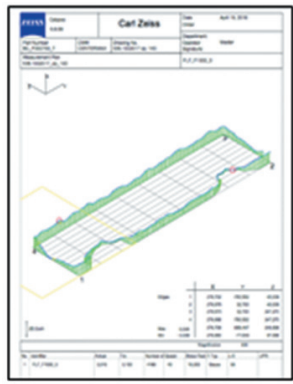

Fig. 10. A fragment of cylinder block mating surface shape accuracy deviations measurement result.

10. ábra Mérési eredmény hengerblokk felületi megmunkálási alakpontosságának eltérésére.

\section{Conclusions}

A dynamical model of multipoint cutting process has been proposed and substantiated. The model is based on a continuum theory where the metal primary plastic deformation zone and the chip coming off the tool face are presented as continuum elements each subjected to a dynamic load imitating a multipoint tool.

The model is largely universal, it is in line with the presentday concepts of the cutting process mechanics. It reflects the elastic response, the plastic flow process and the delay effects in the machined metal in reference to each other.

A mathematical model has been proposed that takes account of the specific nature of the multipoint metal cutting problem and ensures efficient description of various chip formation process modes. The rheological processes taking place during multipoint cutting were studied by computer simulation with the help of LabVIEW 13.0 graphical programming environment. The set of research works implemented by us forms the basis for applying computer simulation methods to solving the crucial tasks of cutting process dynamics and machining modes optimization.

A generalized mathematical model has been implemented, reflecting the multipoint cutting process in view of elasoplastic properties in the dynamics of tool-to-work piece contact interaction and the rheological peculiarities of chip forming process in the active plastic deformation zone. A rheological model has been proposed in the form of a series combination of the elastoviscoplastic relaxing Ishlinsky medium (reflecting the process of primary deformation of the sheared-off layer metal) and the Voigt medium with two elastic-dissipative elements (reflecting the sheared chips deformation and friction process).

We have solved the task of space dynamic modelling of variable conditions based on the developed rheological models reflecting molecular processes interaction in the chip formation zone and the elastic-dissipative characteristics of the machining industrial process system.
Guidelines have been developed for determining elasticdissipative coefficients of the multipoint cutting rheological models, based on a set of analog-digital hardware controlled by LabVIEW 13.0 system.

A set of comparative and experimental studies of work pieces milling with a wide variety of machining parameters has been performed.

A machining stability area has been refined, allowing to increase cutting speed without product quality deterioration. A comparison of calculation and experimental data has shown that the deviation between calculation and experimental data did not exceed $15 \%$, which is evidence of qualitative concrordance of the nature of oscillations and affords grounds for claiming that the rheological models developed by us are operable.

\section{References}

[1] Atkins, A. G. (2003): Modelling metal cutting using modern ductile fracture mechanics: Quantitative explanations for some longstanding problems. International Journal of Mechanical Sciences, Vol. 45, No. 2, pp. 373-396, https://doi.org/10.1016/S0020-7403(03)00040-7

[2] Bäker M. (2003): The influence of plastic properties on chip formation. Computational Materials Science, Vol. 28, pp. 556-562, https://doi.org/10.1016/j.commatsci.2003.08.013

[3] Brown C. A. (1987): Strain analysis in machining using metallographic methods. Metallography, Vol. 20, pp. 465-483, https://doi.org/10.1016/0026-0800(87)90020-6

[4] Ee, K. C. - Balaji, A. K. - Li, P. X. - Jawahir, I. S. (2002): Force decomposition model for tool-wear in turning with grooved tool, Wear, Vol. 249, No. 1011, pp. 985-994. https://doi.org/10.1016/S0043-1648(01)00837-7

[5] Gao, Y. - Sun, R. L. - Chen, Y. N. - Leopold, J. (2016): Mechanical and thermal modeling of modulation-assisted machining. International Journal of Advanced Manufacturing Technology, Vol. 86, No. 9-12, pp. 2945-2959, https://doi.org/10.1007/s00170-016-8421-y

[6] Gonzalez, D. - Simonovski, I. - Withers, P. J. - Quinta Da Fonseca, J. (2014): Modelling the effect of elastic and plastic anisotropies on stresses at grain boundaries. International Journal of Plasticity, Vol. 61, pp. 49-63, https://doi.org/10.1016/j.ijplas.2014.03.012

[7] Madissoo M. - Rossner A. - Maksarov V. - Olt J. (2015): Testing of the external turning tool holder equipped with alternate bars in its construction. Medziagotyra, Vol. 21, No. 3, pp. 391-395, https://doi.org/10.5755/j01.ms.21.3.7351

[8] Maksarov V. - Madissoo M. - Olt J. (2013): Increasing the Effectiveness of the Cutting Process in the Course of Milling. Journal of Mechanics \& Industry Research, Vol. 1, No. 4, pp. 75 -81, https://doi.org/10.12966/jmir.11.02.2013

[9] Martinkovič, M. - Pokorný, P. (2015): Estimation of local plastic deformation in cutting zone during turning. Key Engineering Materials, Vol. 662, pp. 173-176, https://doi.org/10.4028/www.scientific.net/KEM.662.173

[10] Olt J. - Madissoo M. - Maksarov V. (2012): Dynamic stabilization of technological systems for processing edge cutting through local metastability. Proceedings - 2011 IEEE International Symposium on Assembly and Manufacturing, ISAM 2011; Tampere; Finland; 25 May 2011 through 27 May 2011; Category number CFP11ATP-ART; Code 86199, pp. 6 - 12, https://doi.org/10.1109/ISAM.2011.5942348

[11] Olt J. - Maksarov V. (2015): Cutting process simulation on the basis of rheological properties of metals. Annals of DAAAM and Proceedings of the DAAAM symposium. Vienna, Austria, pp. 229-237. https://doi.org/10.2507/26th.daaam.proceedings.032

[12] Olt J. - Liyvapuu, A. - Madissoo M. - Maksarov V. (2016): Dynamic simulation of chip formation in the process of cutting. Journal of Materials \& Product technology, Vol. 53, No. 1, pp. 1-14, https://doi.org/10.1504/JMPT.2016.076363 
[13] Rao G. V. G. - Mahajan P. - Bhatnagar N. (2007): Micro-mechanical modeling of machining of FRP composites - Cutting force analysis. Composes Science and Technology, Vol. 67, No. 3-4. pp. 579-593, https://doi.org/10.1016/j.composcitech.2016.08.010

$\underline{\text { Ref.: }}$

Maksarov, Viacheslav - Khalimonenko, Aleksey - Olt, Jüri: Managing the process of machining on machines on the basis of dynamic modelling for a technological system

Építőanyag - Journal of Silicate Based and Composite Materials, Vol. 69, No. 2 (2017), 66-71. p.

https://doi.org/10.14382/epitoanyag-jsbcm.2017.11
Forgácsolási múvelet vezérlése szerszámgépeken dinamikus modell felhasználásával technológiai rendszerben

A cikk bemutatja cserélhetố kerámia megmunkáló szerszámokkal történố CNC esztergálás hatékonyságának javítási lehetôségeit többpontos megmunkálás során. A szerzốk bemutatnak egy dinamikus modellt, amelynek az alapja a kontinuum elmélet, és egy matematikai modellt, amely követi a többpontos fémmegmunkálási folyamat természetét. A szerzốk a modellek hatékonyságát több forgácsképzôdési módhoz is illusztrálják.

Kulcsszavak: többpontos forgácsolás, dinamikus modell, forgácsolási eljárás, generikus matematikai modell, fúrás.

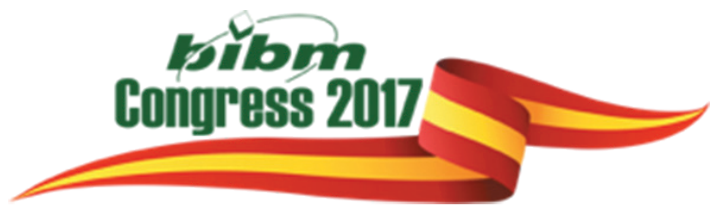

\section{2nd BIBM Congress 2017, Madrid, Spain}

The 22nd BIBM Congress 2017 took place on 17-19 May 2017 in Madrid, Spain with more than 650 registered participants, including exhibitors. The Congress offered more than 30 presentations with three plenary and three parallel sessions showing interesting best examples in sustainable production and promoting sustainable markets. An exhibition with more than 60 companies offered solutions for the planning, design, manufacture and installation of modern precast concrete structures.

After the welcome of BIBM President, ANDECE President and the BIBM Secretariat, the Congress offered a setting the scene session with presentations about the construction sector market conditions and policy developments, the impact of COP 21 on the sector and the impact of European policies on the daily business of concrete producers.

Throughout the Congress, examples from Latin-America varied the EU focus of the lectures and brought a new different insight into the European scene.

Parallel sessions were organised to offer exciting lectures for audience with both technical and marketing background. Its carefully organised schedule enabled participants to switch sessions to listen to a presentation. Networking coffee breaks and lunch breaks took place in the exhibition area where more than 60 exhibitors presented state-of-the-art solutions for the precast industry.

The sustainable production sessions were moderated by Alessio Rimoldi, Secretary General of BIBM and the lectures varied from issues such as circular economy, innovation, Environment Product Declarations (EPDs), health and safety of workers.

Promoting sustainable markets sessions were moderated by Dr. Ulrich Lotz Chairman of BIBM Communication Commission, Gernot Brandweiner Chairman of BIBM Technical Commission and Zsuzsa Amina Koubaa, European Public Affairs Manager of BIBM. Interesting market solutions and new market opportunities were presen

The last plenary Isession presented market developments for concrete such as Rebuilding vs. Renovation, urbanisation and energy saving innovations.
The BIBM General Assembly - held 18 May - elected the new President, Claus Bering from CRH Concrete, who gave his first speech at the Gala Dinner on Thursday evening.

For the next three years, BIBM will continue to advocate for a stable, business friendly legislative environment at European level and fight for an equal level playing field for our industry.

The priority partners and audience of BIBM advocacy work are the EU institutions (Commission, Parliament and Council), as well as European and international construction organisations.

The principal areas of activity are:

- Position precast concrete as a material of choice when it comes to energy efficiency, sustainable construction and circular economy

- Advocate for equal financial aid when rebuilding in comparison to renovation

- Raising the awareness of the importance of the construction sector on the political agenda and importance of long-term policy goals and strategies

- Stabilising the normative frameworks in order to allow for the long-term development and fair competition for precast businesses;

- Promoting innovation, research, communication of the sector in areas like circular economy and fire as key factors o technological advantages

Engage the sector in health and safety issues and pledge to reduce risk to health and safety of all stakehold 